\title{
Forecasting stock index based on hybrid artificial neural network models
}

\author{
Ta Quoc Bao ${ }^{1, *}$, Le Nhat Tan², Le Thi Thanh An ${ }^{3}$, Bui Thi Thien My ${ }^{1}$
}

${ }^{1}$ Banking University of Ho Chi Minh City, Viet Nam

${ }^{2}$ International University, VNUHCM, Viet Nam

${ }^{3}$ University of Economics and Law, VNUHCM, Viet Nam

\section{Correspondence}

Ta Quoc Bao, Banking University of Ho Chi Minh City, Viet Nam

Email: baotq@buh.edu.vn

History

- Received: 06-12-2018

- Accepted: 18-02-2019

- Published: 25-3-2019

DOI :

https://doi.org/10.32508/stdjelm.v3i1.540

\section{Check for updates}

\section{Copyright}

(c) VNU-HCM Press. This is an openaccess article distributed under the terms of the Creative Commons Attribution 4.0 International license.

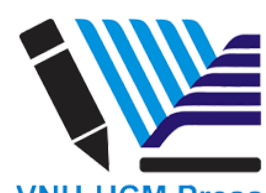

\begin{abstract}
Forecasting stock index is a crucial financial problem which is recently received a lot of interests in the field of artificial intelligence. In this paper we are going to study some hybrid artificial neural network models. As main result, we show that hybrid models offer us effective tools to forecast stock index accurately. Within this study, we have analyzed the performance of classical models such as Autoregressive Integrated Moving Average (ARIMA), Artificial Neural Network (ANN) model and the Hybrid model, in connection with real data coming from Vietnam Index (VNINDEX). Based on some previous foreign data sets, for most of the complex time series, the novel hybrid models have a good performance comparing to individual models like ARIMA and ANN. Regarding Vietnamese stock market, our results also show that the Hybrid model gives much better forecasting accuracy compared with ARIMA and ANN models. Specifically, our results tell that the Hybrid combination model delivers smaller Root Mean Square Error (RMSE) and Mean Absolute Error (MAE) than ARIMA and ANN models. The fitting curves demonstrate that the Hybrid model produces closer trend so better describing the actual data. Via our study with Vietnam Index, it is confirmed that the characteristics of ARIMA model are more suitable for linear time series while ANN model is good to work with nonlinear time series. The Hybrid model takes into account both of these features, so it could be employed in case of more generalized time series. As the financial market is increasingly complex, the time series corresponding to stock indexes naturally consist of linear and non-linear components. Because of these characteristic, the Hybrid ARIMA model with ANN produces better prediction and estimation than other traditional models.
\end{abstract}

Key words: stock index, Hybrid models, Vietnamese stock market, ARIMA model, ANN model.

\section{INTRODUCTION}

In the past two decades, the most popular techniques used in forecasting stock prices are the statistical models and the artificial intelligence models (AI). Some most commonly used methods in the statistical models for time series analysis include, e.g., Autoregressive Integrated Moving Average (ARIMA) or the well-known Box-Jenkins model, Exponential Smoothing model (ESM), and Generalized Autoregressive Conditional Heteroskedasticity (GARCH) volatility. Due to the fact that the mean and variance of financial time series change overtime, and, hence, the series are not linear. More precisely, financial time series often contain both linear and nonlinear patterns. Therefore, one of the main restriction in these traditional models is that they only contain a linear structure. In fact, Refenes et al ${ }^{1}$ showed that the traditional statistical models, such as ARIMA model, for forecasting have main limitations in applications to non-linear data set such as stock indices, exchange rates. The recent development in the theory of computational intelligence provides powerful mathematical tools for private investors, portfolio man- agers and also bankers to exploit the big data, especially, big data in finance. The AI models and machine learning techniques, e.g., the Artificial Neural Network models (ANN) are introduced and utilized to overcome these restrictions. These models contain two components that are linear and non-linear parts. Recently, a new approach which combines ARIMA and ANN models for financial time series has been studied, e.g., in Zhang ${ }^{2}$, Wang et al. ${ }^{3}$. This combination is called the hybrid model. It is showed that the hybrid model gives more accurate result for forecasting time series, especially, for stock prices. The basic idea of hybrid ARIMA and Artificial Neural Network model is that the non-linear patterns can be presented as the residuals of the linear ARIMA model which can be modeled by using artificial neural networks. Furthermore, the relationship between the linear and non-linear components is assumed to be additive. In this study we utilize the hybrid model to forecast VNINDEX stock price. We find out the suitable ARIMA and ANN models for the time series and then find out the appropriate a hybrid model which combines the ARIMA and ANN models. Further- 
more, we compare the results between hybrid model and the individual ARIMA and ANN models in terms of forecasting accuracy based on performance criteria such as Root Mean Square Error (RMSE), Normalized Mean Square Error (NMSE) and Mean Absolute Error (MAE).

\section{FORECASTING METHEDOLOGY}

In this section we give a brief description on ARIMA and Artificial Neural Network models. Furthermore, we demonstrate the basic principle in the hybrid model from ARIMA and ANN models.

\section{The ARIMA model}

ARIMA model was first initiated by Box and Jenkins ${ }^{4}$. This model is one of the most general class of models for forecasting a time series which can be made to be stationary by differencing. More precisely, ARIMA model is generalized from ARMA model (autoregressive moving average) in which the assumption on stationary of time series is not necessary. The important characterization of ARIMA model is that the predictions of the behaviour of a time series in the future depend on the past observations by a linear function and random errors, i.e., the ARIMA equation for forecasting a stationary series $Y_{t}$ has the following form

$$
\begin{aligned}
& \text { predict for } Y_{t} \text { at time } t=\text { constant }+ \text { weighted } \\
& \text { sum of the last } p \text { values of } Y_{t}+\text { weighted sum of } \\
& \text { the last } q \text { values of errors }
\end{aligned}
$$

Intuitively speaking, for a non-stationary time series $X_{t}$, we say that $X_{t}$ is fitted by a $\operatorname{ARIMA}(p, d, q)$ process if

(i) $Y_{t}:=(1-B)^{d} X_{t}$ is a stationary time series, where $B$ is the backward shift operator, i.e., $B^{j} X=X_{t-j}$, $d$ is the number of non-seasonal differences needed for stationarity, it is called integration.

(ii) The stationary series $Y_{t}$ is a $\operatorname{ARMA}(p, q)$ process, i.e., for every $t$

$Y_{t}=\theta_{0}+\phi_{1} Y_{t-1}+\phi_{2} Y_{t-2}+\cdots+\phi_{p} Y_{t-p}+\varepsilon_{t}-$ $\theta_{1} \varepsilon_{t-1}-\theta_{2} \varepsilon_{t-2}-\cdots-\theta_{q} \varepsilon_{t-q}$, where $\varepsilon_{t} \sim N\left(0, \sigma^{2}\right)$ is the random error. The parameter $p$ is the number of autoregressive terms and $q$ is the number of lagged forecast errors in the rediction equation.

It is seen that ARIMA processes have two components which are Autoregressive model (AR) of order $p$ and Moving-Average (MA) model.

\section{The artificial neural network approach}

One of the most important advantages of an Artificial Neural Networks is to approximate various complex non-linear time series. The ANN is developed from statistical learning algorithm based on mimicking the neural networks in the human brain. It can process parallelly information from data, and, hence, the ANN provides a powerful tool for forecasting time series more accurately. The ANN model consists of layers which are an input layer, output layer and single or more hidden layers. However, a single layer is the most common in modelling and forecasting for time series (see, e.g., ${ }^{5}$ ). The algorithm of the ANN can be described as follows. The input layer has one or more inputs where an input is a vector value. Each node in an input layer can be connected to the nodes of the first hidden layer. The data go to the network through hidden layers until attaining the output layer, for example, see the following Figure 1.

Intuitively Speaking, let $Y_{t}$ be a time series. The relationship between the future value (the output) and its past values (the inputs) $Y_{t-1}, Y_{t-2}, \ldots, Y_{t-p}$ can be represented by the following equation

$Y_{t}=a_{0}+\sum_{j=1}^{q} a_{j} f\left(\omega_{0 j}+\sum_{i=1}^{p} \omega_{i j} Y_{t-i}\right)+\varepsilon_{t}$,

Where, $a_{t}$ and $\omega_{i j}, i=1,2, \ldots, p ; j=1,2, \ldots, q$ are parameters of the model. They are called the connection weight between layers of the model. Parameters $p$ and $q$ are the number of input nodes and the number of hidden nodes in the model. The function $f$ is the transfer function of the hidden layer taking the form

$$
f(x)=\frac{1}{1+e^{-x}}
$$

It is seen that $f$ is the logistic function ${ }^{6}$ or the sigmoid function taking values on $[0,1]$. Furthermore, $f$ is real-valued and differentiable and has some properties such as non-positive first derivative with one local minimum and one local maximum. From (1), we see that the ANN model forecasts the future value by performing a non-linear functional mapping of the past observations. Therefore, we can formulate its general mathematical equation as follows

$$
Y_{t}=\varphi\left(Y_{t-1}, Y_{t-2}, \ldots, Y_{t-p}, \omega\right)+\varepsilon_{t},
$$

Where, $\omega$ is the vector of parameter and the function $\phi$ is determined by the network structure and appropriate weights. Therefore, ANN can be seen as a nonlinear autoregressive model.

The main task when dealing with ANN model for a time series is to select a correct the lagged observations $p$ and an appropriate number of hidden nodes $q$. Unfortunately, there is no theoretical methods to guide the selection of these parameters, and, hence, in practice, selecting the appropriate values $p$ and $q$ is often conducted from experiments. 


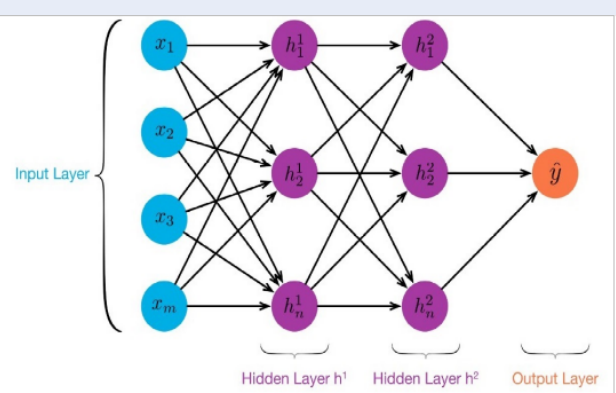

Figure 1: 4-3-3-1neural network model. Source: towardsdatascience.com/multilayer-neural-networks-withsigmoid-function-deep-learning-for-rookies-2-bf464f09eb7f

\section{The hybrid approach}

As far as we know that ARIMA model is a good performance for forecasting linear time series and ANN model is better selection for forecasting non-linear time series. However, both models are not good enough for fitting a more complex time series. Since, a complex time series can be decomposed into a linear component and a non-linear component, e.g., Fourier decomposition. Hence, the hybrid model is employed to model this type of time series in which ARIMA and ANN approaches can be deployed to model the linear component and the non-linear component, respectively (see, ${ }^{2,3,7}$ ). More precisely, a time series $X_{t}$ can be represented as

$$
X_{t}=L_{t}+N_{t}
$$

where $L_{t}, N_{t}$ denote the linear, non-linear components, respectively. These components can be fitted from data. First stage, ARIMA approach is used to model the linear component and, then, the residuals et from the linear model can be seen as the non-linear relationship. Hence, we can apply the ANN approach to this component. Denote $\hat{L}_{t}$ the forecast value at time $t$, we have

$$
e_{t}=X_{t}-\hat{L}_{t} .
$$

By ANN approach, $e_{t}$ takes the form

$$
e_{t}=\varphi\left(e_{t-1}, e_{t-2}, \ldots, e_{t-p}, \omega\right)+\varepsilon_{t},
$$

where, $\varphi$ is a non-linear function determined by the neural network and $\mathscr{E}_{t}$ is the random error. Denote $\hat{N}_{t}$ the forecast value from (4). From (2), (3) and (4) we have the forecast value $\hat{X}_{t}$ of the series

$$
\hat{X}_{t}=\hat{L}_{t}+\hat{N}_{t},
$$

So, there are two steps to perform the hybrid ARIMA neural network model as follows

(i) forecast values $\hat{L}_{t}$ (resulted from ARIMA model)

(ii) forecast residuals $\hat{N}_{t}$ (resulted from ARIMA model) by ANN model

\section{DATA - RESULTS}

\section{Data set}

In this study the weekly closing prices for VNINDEX from January 4, 2006 to September 28, 2018 are used (Figures 2 and 3). There are total 663 trading weeks in this period. The data is divided into two periods, the first period includes 654 weeks (as a training set) that are used for model estimation and the second period includes 9 weeks (as a test set) that is reserved for forecasting and evaluation.

Financial time series are often not stationary, especially stock prices. Transform stock prices into log return prices is the most common method in analysing financial data. Let $P t$ be the stock price at time $t$. The $\log$ returns $R_{t}$ are defined as

$$
R_{t}:=\log \left(\frac{P_{t}}{P_{t-1}}\right)
$$

More details, we refer to ${ }^{8}$ for good properties of $\log$ return. The log returns are also called continuously compounded returns. The plots of stock prices and weekly $\log$ returns are shown in the following Figure 2 and Figure 3.

\section{Error measures}

We introduce some of the most common error measures or accuracy measures widely used for comparing different forecasts in financial time series. These measures are used to identify which methods is one of the most suitable forecast methods. The most preferred measure used for forecasting accuracy of a model is the Root Mean Square Error (RMSE), see, e.g., R. Carbone and J. S. Armstrong ${ }^{9}$ for more details. It is defined as

$$
R M S E:=\sqrt{\frac{\sum\left(Y_{r}-\hat{Y}_{t}\right)^{2}}{N}},
$$

where $N$ is the sample size. 


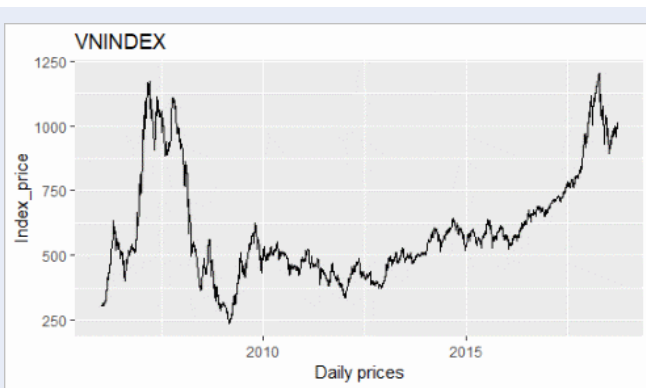

Figure 2: The daily closing prices from January 4, 2006 to September 28, 2018.

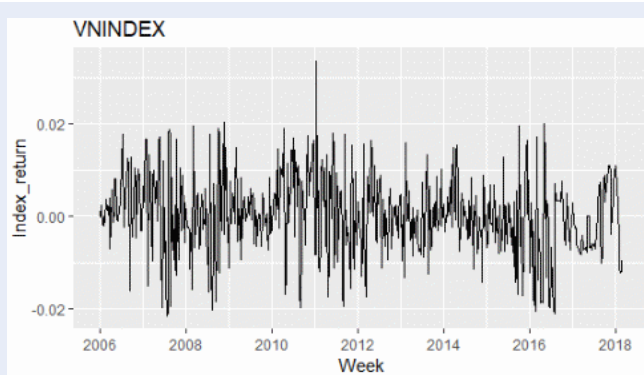

Figure 3: The weekly returns from January 4, 2006 to September 28, 2018.

The following Mean Absolute Percentage Error $(M A P E)$ is also used as a common error measure $\left(\right.$ see $\left.^{10}\right)$

$$
M A P E:=\frac{1}{N} \sum \frac{\left|Y_{t}-\hat{Y}_{t}\right|}{\left|Y_{t}\right|} .
$$

Another most popular error measure is known as the Mean Absolute Error (MAE):

$$
M A E:=\frac{1}{N} \sum\left|Y_{t}-\hat{Y}_{t}\right| .
$$

it is seen that, this measure is easy to both understand and compute.

\section{Results for price data}

We use ARIMA, ANN and Hybrid model to fit VNINDEX data. We compare these models and chose the best model for this data set. There are a number studies fitting financial data by using these models and show that the hybrid model is the best model for fitting and forecasting closing prices of market $\left(\mathrm{see}^{2,3,11,12}\right)$. In case Vietnamese market, we also see that the hybrid is the best model for fitting VNINDEX, see the following table for comparing error measures of these models.

The comparison between the actual values and fitted values of ARIMA and Hybrid models are given in Figure 4. This figure shows that Hybrid model has a good performance in fitting VNINDEX.

\section{DISCUSSIONS}

This work is one first attempt applying sophisticated quantitative models to study VNINDEX. To strengthen our results, further data sets and models should be used for testing and validation. We are going to investigate other stock indexes given in Thomson Reuters database as well as explore potential developed models and their necessary improvement. We also interested in studying whether different indexes coming from different countries favor the same type of models, or create country- associated effect.

\section{CONCLUSIONS}

In this study, we have analyzed the performance classical ARIMA, ANN model and the Hybrid model for describing VNINDEX. Generally, for almost complex time series, the novel hybrid models have a better performance than individual models ARIMA and ANN. For Vietnamese stock market, the results show that the Hybrid model also gives much better forecasting accuracy as compared with ARIMA and ANN models.

\section{ABBREVIATIONS}

AI: Artificial Intelligence

ARIMA: Autoregressive Integrated Moving Average ESM: Exponential Smoothing Model 
Table 1: Error Measures

\begin{tabular}{lll}
\hline & MAE & RMSE \\
\hline ARIMA & 0.006225405 & $6.597903 \mathrm{e}-05$ \\
Hybrid & 0.005496027 & $5.426601 \mathrm{e}-05$ \\
ANN & 0.005751329 & $5.562526 \mathrm{e}-05$ \\
\hline
\end{tabular}

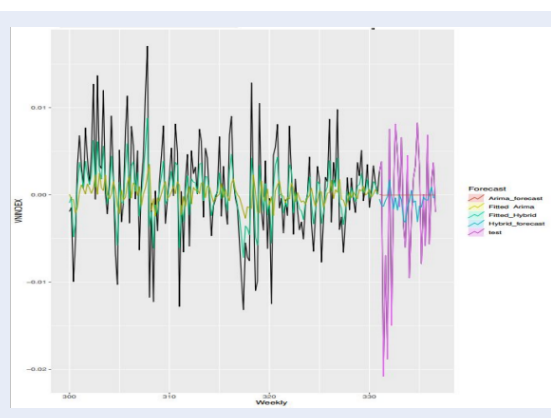

Figure 4: Fitting with ARIMA and Hybrid models.

GARCH: Generalized Autoregressive Conditional Heteroskedasticity

ANN: Artificial Neural Network model

RMSE: Root Mean Square Error

NMSE: Normalized Mean Square Error

MAE: Mean Absolute Error

VNINDEX: Vietnam Index, a capitalizationweighted index of all the companies listed on the Ho Chi Minh City Stock Exchange

\section{COMPETING INTERESTS}

The authors declare that they have no conflict of interest.

\section{AUTHORS' CONTRIBUTIONS}

Ta Quoc Bao and Le Thi Thanh An initiate the idea, study relevant models and seek for the data. Ta Quoc Bao and Le Nhat Tan build the main programs for numerical simulations. All authors check the simulation and contribute for the interpretation of the results. Ta Quoc Bao and Le Thi Thanh An edit and revise the text. All authors check and approve the article.

\section{REFERENCES}

1. Refenes AN, Zapranis A, Francis G. Stock performance modeling using neural networks: a comparative study with regression models. Neural networks. 1994;7(2):375-88. Available from: https://doi.org/10.1016/0893-6080(94)90030-2.

2. Zhang GP. Time series forecasting using a hybrid ARIMA and neural network model. Neurocomputing; 2003.

3. Wang JJ, Wang JZ, Zhang ZG, Guo SP. Stock index forecasting based on a hybrid model. Omega. 2012;40(6):758-66.

4. Box G, Jenkins G. Time Series Analysis, Forecasting and Control. San Francisco, CA: Holden-Day; 1970. .

5. Zhang G, Patuwo BE, Hu MY. Forecasting with artificial neural networks: The state of the art. International journal of forecasting. 1998;14(1):35-62.

6. Jain AK, Mao J, Mohiuddin K. Artificial neural networks: A tutorial. Computer. 1996;(3):31-44. Available from: DOI Bookmark: 10.1109/2.485891.

7. Guresen E, Kayakutlu G, Daim T. Using artificial neural network models in stock market index prediction. Expert Systems with Applications. 2011;38(8):10389-97. Available from: https://d oi.org/10.1016/j.eswa.2011.02.068.

8. Ruppert D, Matteson DS. Statistics and data analysis for financial engineering. Springer; 2015. Available from: DOI 10.1007/978-1-4939-2614-5.

9. Carbone R, Armstrong JS. Note. Evaluation of extrapolative forecasting methods: results of a survey of academicians and practitioners. Journal of Forecasting. 1982;1(2):215-7. https:/ /doi.org/10.1002/for.3980010207.

10. Armstrong JS, Collopy F. Error measures for generalizing about forecasting methods: Empirical comparisons. International journal of forecasting. 1992;8(1):69-80.

11. Aslanargun A, Mammadov M, Yazici B, Yolacan S. Comparison of ARIMA, neural networks and hybrid models in time series: tourist arrival forecasting. Journal of Statistical Computation Simulation. 2007;77(1):29-53.

12. Pai PF, Lin CS. A hybrid ARIMA and support vector machines model in stock price forecasting. Omega. 2005;33(6):497-505. Available from: https://doi.org/10.1016/j.omega.2004.07.024 


\title{
Dự báo chỉ số cổ phiếu bằng các mô hình mạng thần kinh nhân tạo kết hợp
}

\author{
Tạ Quốc Bảo1,* , Lê Nhật Tân², Lê Thị Thanh $\mathrm{An}^{3}$, Bùi Thị Thiên Mỹ ${ }^{1}$
}

\footnotetext{
${ }^{1}$ Trường Đại học Ngân hàng TP HCM

${ }^{2}$ Trường Đại học Quốc tế, ĐHQG HCM

${ }^{3}$ Trường Đại học Kinh tế Luật, ĐHQG HCM

Liên hệ

Tạ Quốc Bảo, Trường Đại học Ngân hàng TP HCM

Email: baotq@buh.edu.vn

Lịch sử

- Ngày nhận: 06-12-2018

- Ngày chấp nhận: 18-02-2019

- Ngày đăng: 25-03-2019

DOI : $10.32508 /$ stdjelm.v3i1.540
}

\section{Check for updates}

\section{Bản quyền}

๑ ĐHQG Tp.HCM. Đây là bài báo công bố mở được phát hành theo các điều khoản của the Creative Commons Attribution 4.0 International license.

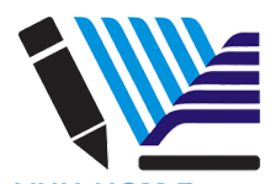

VNU-HCM Press

\section{TÓM TẮT}

Dự báo chỉ số cổ phiếu là một trong những vấn đề tài chính quan trọng và gần đây đã thu hút được nhiều sự quan tâm từ các chuyên gia trong lĩnh vực trí thông minh nhân tạo. Trong nghiên cứu này, chúng tôi sử dụng một số mô hình mạng thần kinh kết hợp. Kết quả chính cho thấy mô hình này cung cấp một công cụ hiệu quả để dự báo chính xác hơn chỉ số chứng khoán. Cụ thể, chúng tôi đã so sánh hiệu quả dự báo chỉ số VNINDEX giữa các mô hình truyền thống ARIMA, ANN và mô hình kết hợp Hybrid ARIMA và ANN. Dựa trên các số liệu từ các nước, đối với hầu hết các chuỗi thời gian phức tạp, mô hình kết hợp mới cho khả năng dự báo tốt hơn so với các mô hình riêng lẻ ARIMA và ANN. Đối với thị trường cổ phiếu Việt Nam, kết quả cũng cho thấy các mô hình kết hợp mới dự báo chính xác hơn đáng kể so với các mô hình ARIMA và ANN. Cụ thể, các kết quả của chúng tôi cho thấy mô hình kết hợp Hybrid cho sai số bé hơn hẳn so với hai mô hình đơn ARIMA và ANN. Các đồ thị xấp xỉ chỉ ra rằng mô hình Hybrid phản ánh chính xác xu hướng tăng giảm và gần với dữ liệu thực tế hơn. Đặc điểm của mô hình ARIMA thường thích hợp cho các chuỗi thời gian tuyến tính trong khi mô hình ANN hay được sử dụng để dự báo cho các chuỗi thời gian phi tuyến. Mô hình Hybrid kết hợp được cả hai yếu tố trên nên có thể sử dụng cho các chuỗi thời gian tổng quát. Do thị trường tài chính ngày càng phức tạp nên đặc điểm của chuỗi thời gian tương ứng với chỉ số chứng khoán thường bao gồm cả hai thành phần tuyến tính và phi tuyến. Vı đặc tính này nên mô hình kết hợp Hybrid ARIMA với ANN cho kết quả dự báo và ước lượng tốt hơn các mô hình truyền thống khác.

Từ khoá: Chỉ số cổ phiếu, các mô hình kết hợp, thị trường cổ phiếu Việt Nam, mô hình ARIMA, ANN

\footnotetext{
Trích dẫn bài báo này: Quốc Bảo $T$, Nhật Tân $L$, Thị Thanh $A n L$, Thị Thiên Mỹ $B$. Dự báo chỉ số cổ phiếu bằng các mô hình mạng thần kinh nhân tạo kết hợp. Sci. Tech. Dev. J. - Eco. Law Manag.; 3(1):52-57.
} 